\title{
PENGARUH PENGGUNAAN MEDIA GAMBAR LEWAT KOMPUTER TERHADAP HASIL BELAJAR FISIKA PADA SISWA KELAS X SMA NEGERI 3 MAKASSAR
}

\author{
Mukarramah Mustari \\ Program Studi Pendidikan Fisika IAIN Raden Intan Lampung \\ e-mail: mukarramahmustari@yahoo.co.id
}

Diterima: 21 Juli 2015 Disetujui: 11 Oktober 2015. Dipublikasikan: Oktober 2015

\begin{abstract}
This study is an experimental research, which aims to obtain information on physics learning outcomes of students of class X SMA Negeri 3 Makassar who follow the learning through the use of media images via computer and follow the conventional learning lesson year 20013/2014. Population in this research is student of class X SMA Negeri 3 Makassar. The research samples used class random technique and obtained two classes. One class is used as an experimental class that follows the learning through the use of computerized image media and one more class as a control class that follows conventional learning with a sample size of 58 students. Data processing of this research using two statistical techniques, namely: 1) Descriptive Analysis Technique to describe the characteristics of student learning outcomes of class X SMA 3 Makassar, 2) Inferential Analysis Technique with " $t$ " test to test the research hypothesis which then becomes chi-square test because one of the data is not normally distributed. The results of inferential analysis obtained information that: "There is a significant difference between students' physics learning outcomes that follow the learning through the use of computerized image media with students who follow the conventional learning in grade X students SMA Negeri 3 Makassar.
\end{abstract}

\begin{abstract}
Abstrak: Penelitian ini merupakan penelitian eksperimen, yang bertujuan untuk mendapatkan informasi hasil belajar fisika siswa kelas X SMA Negeri 3 Makassar yang mengikuti pembelajaran melalui penggunaan media gambar lewat komputer dan yang mengikuti pembelajaran secara konvensional tahun pelajaran 20013/2014. Populasi dalam penelitian ini adalah siswa kelas X SMA Negeri 3 Makassar. Pengambilan sampel penelitian menggunakan teknik random kelas dan diperoleh dua kelas. Satu kelas dijadikan kelas eksperimen yang mengikuti pembelajaran melalui penggunaan media gambar lewat komputer dan satu kelas lagi sebagai kelas kontrol yang mengikuti pembelajaran secara konvensional dengan jumlah sampel 58 orang siswa. Pengolahan data hasil penelitian ini menggunakan dua teknik statistik, yaitu: 1) Teknik Analisis Deskriptif untuk menggambarkan karakteristik hasil belajar siswa kelas $\mathrm{X}$ SMA Negeri 3 Makassar, 2) Teknik Analisis Inferensial dengan uji " $\mathrm{t}$ " untuk menguji hipotesis penelitian yang kemudian menjadi uji chi-kuadrat karena salah satu data tidak berdistribusi normal. Hasil analisis inferensial diperoleh informasi bahwa: "Terdapat perbedaan yang signifikan antara hasil belajar fisika siswa yang mengikuti pembelajaran melalui penggunaan media gambar lewat komputer dengan siswa yang mengikuti pembelajaran secara konvensional pada siswa kelas X SMA Negeri 3 Makassar".
\end{abstract}

Kata Kunci: hasil belajar fisika, media gambar lewat komputer

\section{PENDAHULUAN}

Fisika adalah bidang studi yang biasanya dianggap sulit, tetapi apa sumber kesulitan dalam belajar fisika jarang diselidiki. Sering dikatakan bahwa fisika sulit karena penggunaan Matematika di dalamnya, atau karena siswa tidak bisa menghitung, atau fisika tidak menarik. Penelitian dari dua kadulawarsa dan sejarah, fisika memperlihatkan bahwa salah satu sumber kesulitan utama adalah terjadinya miskonsepsi. Perkembangan alamiah sejak lahir menghasilkan pra-konsepsi di dalam otak manusia yang sangat kuat tetapi sering salah dan yang terus menerus mengganggu perkembangan konsepsi yang benar. Pra-konsepsi itu tidak diketahui oleh pengajar fisika, maka seringkali terjadi kesenjangan antara penjelasan pengajar dan cara berpikir siswa.

Pemerintah telah mengadakan berbagai macam jenis pendidikan dan 
pelatihan, apakah dalam bentuk pendidikan formal ataukah dalam bentuk penataran-penataran, kursus atau semacamnya demi peningkatan mutu tenaga pendidik. Semakin sering guru mengikuti pendidikan dan penataran, maka seorang guru dapat mengembangkan pengetahuannya sehingga tujuan pembelajaran dapat tercapai secara optimal.

Pemerintah juga telah menyediakan fasilitas laboratorium Ilmu Pengetahuan Alam (IPA) yang disertai alat-alatnya bagi sekolah umum dan kejuruan sekalipun, demi menunjang pengetahuan yang akan diserap oleh siswa. Meskipun diakui bahwa fasilitas tersebut terkadang kurang memadai, oleh karena itu seorang guru selain dapat memberikan suatu informasi atau pembelajaran dengan baik juga dituntut untuk mampu menunjukkan kreatifitasnya. Seperti memotivasi siswa untuk melakakukan eksperimen yang alat dan bahannya dapat dijumpai dilingkungan sekolah, seperti komputer.

Ilmu fisika biasa disebut sains yang merupakan cabang dari Ilmu Pengetahuan Alam yang sangat memegang peranan penting dalam bidang teknologi. Pada tingkatan jenjang pendidikan, Sekolah Menegah Atas (SMA) perlu mendapat perhatian yang serius, karena mereka proses belajar yang dilakukan pada jenjang ini sangat mempengaruhi keberhasilan belajar pada jenjang berikutnya. Siswa dituntun untuk memahami konsep-konsep fisika dengan cara menemukan sendiri cara menyelesaikan suatu masalah yang mereka temukan. Maka pengetahuan yang diperoleh dari proses belajar maupun pengalaman belajar, akan lebih bermakna sehingga perlu diterapkan suatu metode mengajar yang sesuai dengan materi yang diajarkan. Misalnya melakukan eksperimen, dimana kelancaran eksperimen tersebut harus di dukung dengan tersedianya alat-alat di sekolah. Kendala yang biasanya dihadapi oleh sekolah-sejolah adalah keterbatasan komputer.

Pada dasarnya dalam pencapaian tuntutan kurikulum, suatu pembelajaran hendaknya mengarah pada tiga hal pokok yaitu tujuan pembelajaran, metode pembelajaran, serta alat evaluasi. Terkusus pada mata pelajaran fisika, umumnya ketiga hal tersebut telah dilaksanakan, namun kenyataan hasil belajar yang dicapai siswa masih tergolong rendah. Salah satu penyebab rendahnya mutu pendidikan dikarenakan metode yang digunakan belum bisa membuat siswa lebih aktif dalam belajar. Guru masih mendominasi kegiatan pembelajaran sehingga siswa menjadi pasif dan hanya berharap sodoran dari guru. Di mana kegiatan pembelajaran masih didominasi oleh guru menyebabkan siswa kurang mendapat kesempatan untuk mengeluarkan ide-ide dan kurang terjadi interaksi di antara siswa. Sehubungan dengan itu, guru mata pelajaran fisika dalam menyampaikan konsep-konsep fisika diharapkan mampu menggunakan dan mengembangkan metode pembelajaran yang sesuai materi. Guru juga dituntut agar dalam mengajarkan konsep-konsep fisika selalu memperhatikan faktor-faktor yang dapat mempengaruhi tujuan pembelajaran secara optimal. (Slameto:2003).

Sampai sekarang pendidikan kita masih didominasi oleh pandangan bahwa pengetahuan sebagai perangkat faktafakta yang harus dihafal. Kelas masih berfokus pada guru sebagai sumber utama pengetahuan, kemudian ceramah menjadi pilihan utama strategi belajar. Untuk itu diperlukan sebuah strategi belajar baru yang lebih memberdayakan siswa. Sebuah strategi belajar yang tidak mengharuskan siswa menghafal faktafakta, tetapi sebuah strategi yang mendorong siswa mengkontruksikan di benak mereka sendiri. Dalam proses 
belajar, anak belajar dari pengalaman sendiri, mengkonstruksi pengetahuan kemudian memberi makna pada pengetahuan itu. Melalui proses belajar yang mengalami sendiri, menemukan sendiri, secara berkelompok seperti bermain, maka anak menjadi senang, sehingga tumbuhlah minat untuk belajar, khususnya belajar Fisika.

Berdasarkan hasil kunjungan di SMA Negeri 3 Makassar, salah satu penyebab rendahnya hasil belajar siswa di sekolah tersebut adalah penggunaan metode konvensional. Berdasarkan hal tersebut diatas, maka penulis berminat untuk melakukan penelitian yang berjudul "Pengaruh Penggunaan Media Gambar Lewat Komputer Terhadap Hasil Belajar Fisika Siswa Pada Siswa Kelas X SMA Negeri 3 Makassar".

Pengetahuan merupakan segala sesuatu yang diketahui oleh seseorang, tanpa menghiraukan benar dan salahnya, serta dari mana datangnya. Manusia memperoleh pengetahuan dari berbagai sumber, sumber utama adalah panca indra.

Menurut Hendro Darmojo (1986), bahwa pengetahuan yang diperoleh dari panca indra dan bersumber dari pengetahuan alam yang kongkrit memiliki sifat yang faktual. Sumber pengetahuan lain yang tak kala pentingnya adalah fikiran. Hal dimaksud karena melalui proses berfikir orang dapat memperoleh pengetahuan sebatas orang berfikir, terlepas benar atau salahnya pikiran itu, seperti halnya pada proses pembelajaran dengan menggunakan komputer sangat dibutuhkan proses berfikir dan juga panca indra untuk dapat labih memperoleh pengetahuan pembelajaran yang lebih.

\section{METODE PENELITIAN}

Jenis penelitian ini yaitu penelitian eksperimen sungguhan. Lokasi penelitian bertempat di SMA Negeri 3 Makassar Jl.
Baji Areng Cendrawasih Kota Makassar. Variabel pada penelitian ini adalah:

1. Variabel bebas: Penggunaan media pembelajaran dengan level:

a. Pembelajaran media gambar lewat komputer

b. Pembelajaran konvensional

2. Variabel terikat: Hasil belajar

Desain yang digunakan dalam penelitian ini adalah Posttest-Only Control Group Design yang merupakan salah satu jenis penelitian eksperimen sesungguhnya dengan desain sebagai berikut:

$$
\begin{array}{lcc}
\mathbf{R} & \mathbf{X} & \mathbf{O}_{1} \\
\mathbf{R} & - & \mathbf{O}_{2}
\end{array}
$$

(Sugiyono, $2008: 112$ )

Keterangan :

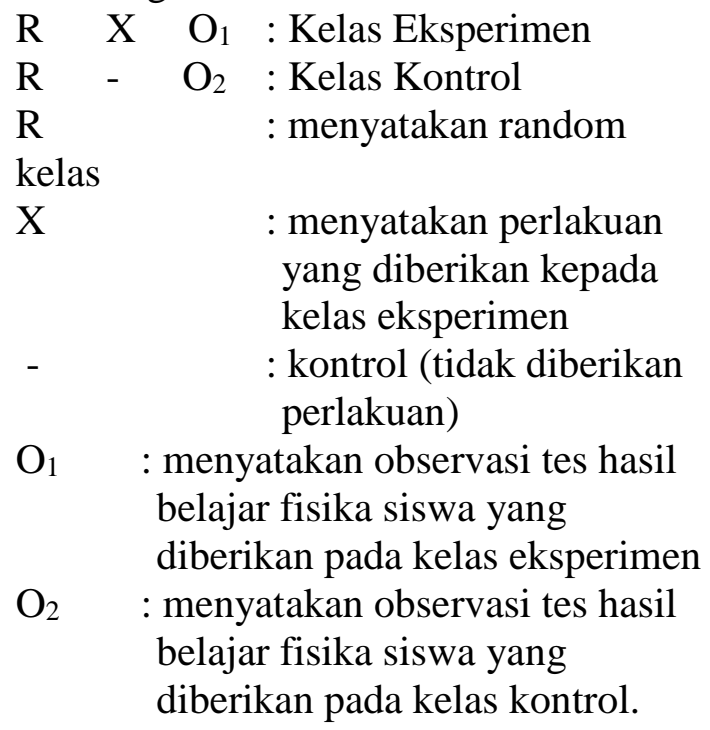

\section{Defenisi Operasional Variabel}

1. Pembelajaran dengan media komputer adalah penyajian bahan pelajaran fisika yang dituangkan dalam bentuk gambar yang menampilkan gambar dan uraian materi yang dibuat berdasarkan tujuan pembelajaran khusus yaitu pada materi Suhu dan Kalor.

2. Pembelajaran secara konvensional adalah pembelajaran dimana cara mengajar melalui penuturan dan penjelasan guru kepada siswa secara 
lisan tanpa menggunakan media gambar lewat komputer.

3. Hasil belajar adalah skor total responden melalui tes hasil belajar fisika dalam ranah kognitif meliputi pengetahuan, pemahaman, aplikasi, analisis, sintesis, dan evaluasi.

\section{Populasi dan Sampel}

Populasi dalam penelitian ini adalah semua siswa kelas X SMA Negeri 3 Makassar Tahun ajaran 20013/20014 yang berlokasi di Jalan Baji Areng Cendrawasih sebanyak 9 kelas dengan jumlah keseluruhan siswa sebanyak 268 siswa dengan rincian sebagai berikut :

Tabel 1. Subyek populasi siswa kelas X SMA Negeri 3 Makassar

\begin{tabular}{cc}
\hline KELAS & JUMLAH SISWA \\
\hline $\mathrm{X}_{1}$ & 31 \\
\hline $\mathrm{X}_{2}$ & 29 \\
\hline $\mathrm{X}_{3}$ & 29 \\
\hline $\mathrm{X}_{4}$ & 30 \\
\hline $\mathrm{X}_{5}$ & 29 \\
\hline $\mathrm{X}_{6}$ & 31 \\
\hline $\mathrm{X}_{7}$ & 30 \\
\hline $\mathrm{X}_{8}$ & 30 \\
\hline $\mathrm{X}_{9}$ & 29 \\
\hline
\end{tabular}

\section{Pengambilan sampel dalam penelitian ini dilakukan dengan} menggunakan simple random sampling. Berdasarkan teknik ini terpilih dua kelas sebagai sampel, yaitu kelas eksperimen dan kelas kontrol. Hasil pengundian tersebut terpilih kelas $\mathrm{X}_{2}$ sebagai kelas eksperimen dengan jumlah siswa sebanyak 29 orang dan kelas $\mathrm{X}_{5}$ sebagai kelas kontrol dengan jumlah siswa sebanyak 29 orang.

\section{Desain Media Pembelajaran}

Pembuatan media pembelajaran fisika dengan menggunakan gambar lewat komputer menggunakan tiga tahap sebagai berikut:

1. Tahap persiapan
Pada tahap ini dilakukan pengumpulan materi pelajaran Suhu dan Kalor dari buku-buku fisika SMU kelas $\mathrm{X}$ dan berbagai sumber belajar lainnya. Setelah materi telah selesai dikumpul, langkah selanjutnya ialah membuat konsep media gambar lewat komputer dengan menggunakan macromedia dan power point.

2. Tahap pelaksanaan

Tahap pelaksanaan merupakan tahap pengembangan fisik media pembelajaran. Media ini diakses melalui internet, dirancang, dan dikutip melalui buku penuntun.

3. Tahap pengujian

Tahap terakhir dalam rancangan penelitian ini adalah melakukan pengujian dan evaluasi pada media pembelajaran yang telah dihasilkan.

\section{Pelaksanaan Penelitian}

Penelitian ini dilaksanakan melalui tiga tahap yaitu tahap persiapan, tahap pelaksanaan dan tahap akhir penelitian.

1. Tahap persiapan

Pada tahap ini kegiatan yang dilakukan peneliti adalah sebagai berikut:

a. Observasi ke sekolah penelitian.

b. Menyusun dan melaksanakan seminar proposal pada tanggal 16 Januari 2014.

c. Membuat persiapan mengajar.

d. Mengurus izin penelitian ke sekolah tempat penelitian.

e. Menyusun tes hasil belajar yang akan diberikan pada siswa.

2. Tahap Pelaksanaan

Pada tahap ini kegiatan yang dilakukan peneliti adalah sebagai berikut:

a. Mengajar di kelas $\mathrm{X}_{2}$ sebagai kelas eksperimen dengan memberikan pembelajaran Suhu dan Kalor dengan menggunakan media gambar lewat komputer.

b. Memperhatikan metode mengajar guru dalam kelas $\mathrm{X}_{5}$ sebagai kelas 
kontrol dengan pembelajaran Suhu dan Kalor secara konvensional.

c. Mengadakan uji tes hasil belajar fisika siswa kelas $X_{3}$ pada hari Senin tanggal 23 Maret 2014 untuk mencari validitas setiap item.

\section{Tahap Akhir}

Tahap ini merupakan tahap pengumpulan data dengan jalan memberikan tes hasil belajar fisika kepada siswa kelas eksperimen dan kelas kontrol pada hari Selasa tanggal 24 Maret 2014. Dimana tes hasil belajar fisika telah diujicobakan sebelumnya. Langkah selanjutnya, data yang diperoleh pada penelitian ini dianalisis.

\section{Teknik Pengumpulan Data}

Dengan mengacu pada keperluan data, dipilihlah jenis instrumen penelitian yang relevan yaitu tes hasil belajar fisika. Pengumpulan data tes hasil balajar dilakukan setelah dilaksanakan proses pembelajaran dengan menggunakan tes hasil belajar fisika untuk mengukur seberapa besar hasil belajar fisika siswa kelas $\mathrm{X}_{2}$ dan $\mathrm{X}_{5}$ SMA Negeri 3 Makassar yang mengikuti pembelajaran dengan menggunakan media gambar lewat komputer dan pembelajaran secara konvensional.

1. Penyusunan Instrumen Hasil Belajar

a. Menyusun kisi-kisi tes hasil belajar fisika yang dibuat dan dikembangkan sendiri oleh peneliti pada pokok bahasan Suhu dan Kalor. Kisi-kisi tes ini dibuat enam jenis dalam ranah kognitif yang meliputi: pengetahuan (C1), pemahaman (C2), aplikasi (C3), analisis (C4), sintesis (C5), dan evaluasi (C6) .

b. Membuat 52 item yang telah dikonsultasikan dengan pembimbing, bentuk tes yang digunakan adalah bentuk pilihan ganda dimana setiap item dilengkapi dengan empat pilihan jawaban. Salah satu dari keempat pilihan jawaban tersebut adalah merupakan kunci jawaban, sedangkan pilihan jawaban yang lain merupakan jawaban yang salah.

c. Tes hasil belajar fisika diujicobakan lalu dianalisis sebelum digunakan dalam penelitian sebenarnya. Hal ini dilakukan untuk melihat soal-soal yang valid dan tidak valid. Komponen yang dianalisis dalam penelitian ini adalah validitas item dan reliabilitas item tes hasil belajar fisika. Waktu pelaksanaan ujicoba instrumen tes hasil belajar fisika ini pada hari Senin tanggal 23 Maret 2014 di kelas $\mathrm{X}_{3}$ dengan jumlah responden 28 siswa.

2. Pelaksanaan Ujicoba Instrumen

Pelaksanaan ujicoba instrumen dilakukan untuk menguji validitas dan reliabilitas item. Untuk menentukan validitas setiap item tes hasil belajar Fisika siswa maka digunakan rumus sebagai berikut:

$$
\gamma_{p b i}=\frac{M_{p}-M_{t}}{S_{t}} \sqrt{\frac{P}{q}}
$$

(Suharsimi Arikunto, 2001: 79)

Keterangan:

$\gamma_{p b i}=$ koefisien korelasi biserial

$M_{p} \quad=$ rerata skor dari subyek yang menjawab betul bagi item yang dicari validitasnya

$M_{T} \quad=$ rerata skor total

Untuk

$S_{t} \quad=$ standar deviasi dari skor total

$P \quad=$ proporsi siswa yang menjawab benar

$\left(p=\frac{\text { banyaknya siswa yang menjawab benar }}{\text { jumlah seluruh siswa }}\right)$

$q \quad=$ proporsi siswa yang menjawab salah $(q=1-p)$

Valid tidaknya item ke-i ditunjukkan dengan membandingkan $\gamma_{p b i}$ 
dengan $\gamma_{\text {tabel }}$ pada taraf signifikan $\alpha=0,05$ dengan kriteria sebagai berikut:

Jika nilai $\gamma_{p b i} \geq \gamma_{\text {tabel }}$, soal dinyatakan valid, dan

Jika nilai $\gamma_{p b i}<\gamma_{\text {tabel }}$, soal dinyatakan tidak valid (drop)

Dari 52 item yang diujicobakan setelah dianalisis diperoleh 20 item yang memenuhi kriteria valid dan 32 item invalid

3. Pemberian Tes Hasil Belajar

Tes hasil belajar Fisika diberikan pada masing-masing kelas (kelas kontrol dan kelas eksperimen). Adapun waktu pelaksanaan pengumpulan data dalam penelitian ini untuk mengetahui hasil belajar fisika siswa yaitu pada hari Selasa 24 Maret 2014 dimana pada kelas eksperimen dilaksanakan pada jam 12.30-13.45 Wita dan pada kelas kontrol dilaksanakan pada jam 07.15-09.00 Wita.

\section{Teknik Analisis Data}

\section{Analisis Statistik Deskriptif}

Statistik deskriptif digunakan untuk mengetahui skor rata-rata, nilai tertinggi, nilai terendah, tabel distribusi frekuensi dan persentase hasil belajar fisika siswa kelas X SMA Negeri 3 Makassar yang diajar melalui media gambar lewat komputer dan yang tidak diajar melalui media gambar lewat komputer (kelas eksperimen dan kelas kontrol). Analisis ini dilakukan untuk menjawab permasalahan 1 dan 2 yakni seberapa besar hasil belajar fisika siswa kelas $\mathrm{X}$ SMA Negeri 3 Makassar yang diajar melalui media gambar lewat komputer dan seberapa besar hasil belajar fisika siswa kelas X SMA Negeri 3 Makassar yang tidak diajar melalui media gambar lewat komputer.

Untuk mengetahui nilai yang diperoleh siswa, maka skor diubah ke nilai menggunakan rumus sebagai berikut:

$$
\mathrm{N}=\frac{\mathrm{SS}}{\mathrm{SI}} \times 100
$$

Keterangan:

$$
\begin{array}{ll}
\mathrm{N} & =\text { nilai siswa } \\
\mathrm{SS} & =\text { skor yang diperoleh siswa } \\
\mathrm{SI} & \text { = skor ideal }
\end{array}
$$$$
\text { (Sudjana, } 2005: \text { 50) }
$$

Pengkategorian deskriptif hasil belajar siswa berdasarkan pengkategorian menurut Arikunto sebagai berikut:

Tabel 2. Pengkategorian deskriptif hasil belajar siswa

\begin{tabular}{cc}
\hline $\begin{array}{c}\text { Interval Nilai hasil belajar Siswa Pada } \\
\text { Pembelajaran Fisika }\end{array}$ & Kategori Hasil Belajar \\
\hline $81-100$ & Sangat baik \\
$66-80$ & Baik \\
$56-65$ & Cukup \\
$41-55$ & Kurang \\
$0-40$ & Gagal \\
\hline
\end{tabular}

\section{Analisis Statistik Inferensial}

Analisis statistik inferensial digunakan untuk menguji hipotesis penelitian yang telah diajukan. Sebelum dilakukan pengujian hipotesis, maka terlebih dahulu diuji dengan menggunakan uji normalitas dan uji homogenitas.

a. Uji Normalitas
Tujuan pengujian ini adalah untuk mengetahui apakah data yang diperoleh berasal dari populasi yang berdistribusi normal atau tidak. Pada pengujian ini digunakan rumus Chi-kuadrat dengan rumus sebagai berikut:

$$
x^{2}=\sum_{i=1}^{k}\left[\frac{\left(O_{i}-E_{i}\right)^{2}}{E_{i}}\right]
$$

(Sudjana, 2005) 
Keterangan:

$x^{2}=$ Chi-kuadrat

$k=$ Banyaknya kelas interval

$O_{i} \quad=$ Frekuensi penggunaan

$E_{i} \quad=$ Frekuensi yang diharapkan

Kriteria Pengujian:

Apabila $x_{\text {hitung }}^{2}<x_{\text {tabel }}^{2}$ dengan derajat kebebasan $(\mathrm{dk})=\mathrm{k}-3$ pada taraf signifikan $\alpha=0,05$, maka diasumsikan data berasal dari populasi yang berdistribusi normal. Sebaliknya apabila $x_{\text {hitung }}^{2}>x_{\text {tabel }}^{2}$ dengan derajat kebebasan $(\mathrm{dk})=\mathrm{k}-3$ pada taraf signifikan $\alpha=$ 0,05 , maka diasumsikan data berasal dari populasi yang tidak berdistribusi normal.

\section{b. Uji Homogenitas}

Uji homogenitas dilakukan untuk mengetahui apakah data yang diperoleh bersifat homogen atau tidak. Pengujian homogenitas dilakukan dengan menggunakan uji-F dengan rumus sebagai berikut:

$$
F=\frac{\text { Varians Terbesar }}{\text { Varians Terkecil }}
$$

(Subana, 2000:171)

\section{Kriteria Pengujian:}

Jika nilai $F_{\text {hitung }}<F_{\text {tabel }}$ dengan derajat kebebasan masing-masing sesuai dengan pembilang dan penyebut pada taraf signifikan $\alpha=0,05$, maka data tersebut bersifat homogen. Sebaliknya jika nilai $F_{\text {hitung }}>F_{\text {tabel }}$ maka data tersebut bersifat tidak homogen.

c. Pengujian Hipotesis

Pengujian hipotesis dilakukan dengan menggunakan uji-t dengan rumus:

Dimana:

$$
t_{\text {hitung }}=\frac{X_{1}-X_{2}}{\sqrt[s]{\frac{1}{n_{1}}+\frac{1}{n_{2}}}}
$$

Keterangan:

$$
S^{2}=\frac{\left(n_{1}-1\right) S_{1}^{2}+\left(n_{2}-1\right) S_{2}^{2}}{n_{1}+n_{2}-2}
$$

$X_{1} \quad=$ Rata-rata nilai siswa yang mengikuti pembelajaran secara konvensional

$X_{2} \quad=$ Rata-rata nilai siswa yang mengikuti pembelajaran dengan media komputer bergambar

$S_{1}^{2} \quad=$ Variansi sampel yang mengikuti pembelajaran secara konvensional

$S_{2}^{2} \quad=$ Variansi sampel yang mengikuti pembelajaran dengan media komputer bergambar

$n_{1} \quad=$ Jumlah sampel yang mengikuti pembelajaran secara konvensional

$n_{2} \quad=$ Jumlah sampel yang mengikuti pembelajaran dengan media komputer bergambar

Hipotesis Statistik:

Digunakan uji dua pihak menggunakan asumsi sebagai berikut:

$$
\begin{gathered}
\text { Ho }: \mu_{1}=\mu_{2} \\
\mathrm{H}_{1}: \mu_{1} \neq \mu_{2}
\end{gathered}
$$

Kriteria pengujian:

Jika nilai $t_{\text {hitung }}>t_{\text {tabel }}$ pada taraf signifikan $\alpha=0,05$ dan $\mathrm{dk}=\mathrm{n}_{1}+\mathrm{n}_{2}-2$ maka Ho ditolak dan $\mathrm{H}_{1}$ diterima, berarti ada perbedaan berarti antara siswa yang mengikuti pembelajaran melalui media komputer bergambar dengan yang mengikuti pembelajaran secara konvensional. Sebaliknya Jika nilai $t_{\text {hitung }}<t_{\text {tabel }}$ maka Ho diterima dan $\mathrm{H}_{1}$ ditolak yang berarti tidak ada perbedaan yang berarti antara siswa yang mengikuti pembelajaran melalui media komputer bergambar dengan yang mengikuti pembelajaran secara konvensional.

Oleh karena data berasal dari populasi yang berdistribusi tidak normal, yaitu data hasil belajar siswa yang mengikuti pembelajaran melalui media gambar lewat komputer (kelas eksperimen ) maka uji hipotesis dengan uji-t tidak dapat dilakukan. Uji-t dapat digunakan jika kedua data berdistribusi normal. Sebagai gantinya dapat dilakukan uji non-parametrik. Salah satu uji non-parametrik yang digunakan dalam 
penelitian ini adalah uji chi-kuadrat dengan persamaan berikut:

$$
x^{2}=\sum \frac{\left(f_{0}-f_{h}\right)^{2}}{f_{h}}
$$

(Suharsimi Arikunto,2006

:290)

Keterangan:

$x^{2} \quad=$ Kai kuadrat (chi-kuadrat)

$f_{0} \quad=$ Frekuensi yang diamati

$f_{h} \quad=$ Frekuensi yang diharapkan

Dengan kriteria sebagai berikut:

$\mathrm{H}_{0}: \mu_{1}=\mu_{2} \quad$ : Tidak terdapat perbedaan yang signifikan antara hasil belajar siswa yang mengikuti pembelajaran melalui media gambar lewat komputer dengan siswa yang mengikuti pembelajaran secara konvensional pada siswa kelas X SMA Negeri 3 Makassar.

$\mathrm{H}_{1}: \mu_{1} \neq \mu_{2} \quad:$ Terdapat perbedaan yang

signifikan antara hasil
belajar siswa yang
mengikuti
pembelajaran melalui
media gambar lewat
komputer dengan siswa
yang mengikuti
pembelajaran secara
konvensional pada
siswa kelas X SMA
Negeri 3 Makassar.

Dengan kriteria pengujian yaitu Ho diterima jika harga Chi-Kuadrat hitung lebih kecil dari Chi-Kuadrat tabel $x_{\text {hitung }}^{2}<x_{(1-\alpha)(s-1)(k-1)}^{2}$. Dan ditolak jika harga Chi-kuadrat hitung lebih besar dengan Chi-Kuadrat tabel $x_{\text {hitung }}^{2}>$ $x_{(1-\alpha)(s-1)(k-1)}^{2}$ atau $\mathrm{H}_{1}$ diterima.

\section{HASIL DAN PEMBAHASAN} 1. Hasil Analisis Statistik Deskriptif

Berikut ini dikemukakan hasil analisis deskriptif siswa kelas X SMA Negeri 3 Makassar tahun pelajaran 2013/2014 yang diajar dengan menggunakan media gambar lewat komputer dan pembelajaran secara konvensional.

a. Siswa kelompok Eksperimen (dengan media)

Berdasarkan hasil analisis deskriptif terlihat bahwa nilai hasil belajar fisika disajikan dalam tabel berikut:

Tabel 3: Deskripsi distribusi nilai hasil belajar fisika siswa yang mengikuti pembelajaran melalui media gambar lewat komputer

\begin{tabular}{lc}
\hline \multicolumn{1}{c}{ Statistik } & Nilai Statistik \\
\hline Ukuran Sampel & 29 \\
\hline Nilai Maksimum & 90 \\
\hline Nilai Minimum & 45 \\
\hline Rentang Nilai & 45 \\
\hline Rata-rata Nilai & 68,13 \\
\hline Standar Deviasi & 12,61 \\
\hline Varians & 159,12 \\
\hline
\end{tabular}

Skor maksimum yang dicapai oleh siswa yang diberikan pembelajaran dengan menggunakan media gambar lewat komputer dalam pembelajaran fisika, yaitu 90 dan skor terendah yang dicapai siswa adalah 45 dari skor total 100 yang mungkin dicapai. Skor rata-rata siswa 68,14 dengan standar deviasi 12,61 (perhitungan selengkapnya dapat dilihat pada lampiran VI).

Jika skor kemampuan analisis problem fisika siswa kelas X SMA Negeri 3 Makassar dikategorikan berdasarkan pengakategorian yang dikemukakan oleh Arikunto tahun 2005, maka dapat dibuat tabel distribusi frekuensi sebagai berikut: 
Tabel 4. Distribusi frekuensi dan persentase tes hasil belajar fisika siswa pembelajaran dengan menggunakan media gambar lewat komputer.

\begin{tabular}{ccccc}
\hline $\begin{array}{c}\text { Interval persentase } \\
(\%)\end{array}$ & Interval Skor & Kategori & Frekuensi & Persentase $(\%)$ \\
\hline $81-100$ & $17-20$ & Sangat Baik & 4 & 9.38 \\
\hline $66-80$ & $13-16$ & Baik & 10 & 46.88 \\
\hline $56-65$ & $9-12$ & Cukup & 10 & 15.62 \\
\hline $41-55$ & $5-8$ & Kurang & 5 & 28.12 \\
\hline$\leq 40$ & $0-4$ & Gagal & 0 & 0 \\
\hline & Jumlah & & 29 & 100 \\
\hline
\end{tabular}

Berdasarkan Tabel 2, maka dapat diketahui bahwa kemampuan analisis problem fisika siswa yang diajar dengan menggunakan media gambar lewat komputer tahun pelajaran 2013/2014 tergolong dalam kategori "baik". b. Siswa Kelompok Kontrol (tanpa media/pembelajaran konvensional)

Nilai hasil belajar fisika disajikan dalam tabel berikut:

Tabel 5. Deskripsi distribusi nilai hasil belajar fisika siswa yang mengikuti pembelajaran secara konvensional

\begin{tabular}{lc}
\hline \multicolumn{1}{c}{ Statistik } & Nilai Statistik \\
\hline Ukuran Sampel & 29 \\
\hline Nilai Maksimum & 80 \\
\hline Nilai Minimum & 35 \\
\hline Rentang Nilai & 45 \\
\hline Rata-rata Nilai & 57,58 \\
\hline Standar Deviasi & 14,55 \\
\hline Varians & 211,82 \\
\hline
\end{tabular}

Skor maksimum yang dicapai oleh siswa yang diberikan pembelajaran dengan metode pembelajaran konvensional (tanpa menggunakan media) dalam pembelajaran fisika, yaitu 80 dan skor terendah yang dicapai siswa adalah 35 dari skor total 100 yang mungkin dicapai. Skor rata-rata siswa 57,58 dengan standar deviasi 14,55 (perhitungan selengkapnya dapat dilihat pada lampiran VI).

Jika skor kemampuan belajar fisika siswa kelas X SMA Negeri 3 Makassar dikategorikan berdasarkan pengakategorian yang dikemukakan oleh Arikunto tahun 2005, maka dapat dibuat tabel distribusi frekuensi sebagai berikut:

Tabel 6. Distribusi frekuensi dan persentase tes hasil belajar fisika siswa

\begin{tabular}{ccccc}
\hline \multicolumn{2}{c}{ dengan metode pembelajaran konvensional } & & \\
$\begin{array}{c}\text { Interval } \\
\text { persentase }(\%)\end{array}$ & $\begin{array}{c}\text { Interval } \\
\text { Skor }\end{array}$ & Kategori & Frekuensi & Persentase (\%) \\
\hline $81-100$ & $17-20$ & Sangat Baik & 0 & 0 \\
\hline $66-80$ & $13-16$ & Baik & 8 & 19.35 \\
\hline $56-65$ & $9-12$ & Cukup & 6 & 16.13 \\
\hline $41-55$ & $5-8$ & Kurang & 11 & 41.94 \\
\hline$\leq 40$ & $0-4$ & Gagal & 4 & 16.13 \\
\hline & Jumlah & & 29 & 100 \\
\hline
\end{tabular}


Berdasarkan Tabel 6, maka dapat diketahui bahwa kemampuan belajar fisika siswa yang diajar dengan metode pembelajaran konvensional (tanpa menggunakan media gambar lewat komputer) tahun pelajaran 2013/2014 tergolong dalam kategori "kurang".

\section{Hasil Analisis Statistik Inferensial}

Pengujian dasar-dasar analisis yang dilakukan meliputi pangujian normalitas. Pengujian normalitas data hasil belajar fisika siswa kelompok eksperimen (dengan media gambar lewat komputer) dan kelompok kontrol (tanpa media gambar lewat komputer) digunakan metode statistik sebagai berikut:

a. Pengujian Normalitas

1) Uji normalitas data hasil belajar fisika siswa kelas X SMA Negeri 3 Makassar yang mengikuti pembelajaran melalui media gambar lewat komputer.

Hasil pengujian normalitas dengan menggunakan rumus Chi-kuadrat, diperoleh nilai $x_{\text {hitung }}^{2}=4,95$ sedangkan $x^{2}(0,05)(3)=x_{\text {tabel }}^{2}=7,81$. Karena $x^{2}$ hitung $<$ $x^{2}$ tabel maka dapat disimpulkan bahwa data hasil belajar fisika siswa kelas $\mathrm{X}$ SMA Negeri 3 Makassar yang mengikuti pembelajaran melalui media gambar lewat komputer berasal dari populasi yang berdistribusi normal (perhitungan selengkapnya dapat dilihat pada lampiran VIII).

2) Uji normalitas data hasil belajar fisika siswa kelas X SMA Negeri 3 Makassar yang mengikuti pembelajaran secara konvensional.

Hasil pengujian normalitas dengan menggunakan rumus Chi-kuadrat, diperoleh nilai $x^{2}{ }_{\text {hitung }}=22,66$ sedangkan $x^{2}(0,05)(3)=x_{\text {tabel }}^{2}=7,81$. karena $x^{2}{ }_{\text {hitung }}>$ $x^{2}$ tabel maka dapat disimpulkan bahwa data hasil belajar fisika siswa kelas $\mathrm{X}$ SMA Negeri 3 Makassar yang mengikuti pembelajaran secara konvensional berasal dari populasi yang berdistribusi tidak normal pada taraf nyata $\alpha=0,05$. ( perhitungan selengkapnya dapat dilihat pada lampiran VIII).

Oleh karena data berasal dari populasi yang berdistribusi tidak normal, maka uji hipotesis dengan uji-t tidak dapat dilakukan. Sebagai gantinya dapat dilakukan uji non-parametrik. Salah satu uji non-parametrik yang digunakan dalam penelitian ini adalah uji chikuadrat dengan persamaan berikut:

$$
x^{2}=\sum \frac{\left(f_{0}-f_{h}\right)^{2}}{f_{h}}
$$

Keterangan:

$$
\begin{array}{ll}
x^{2} & =\text { Kai kuadrat (chi-kuadrat) } \\
f_{0} & =\text { Frekuensi yang diamati } \\
f_{h} & =\text { Frekuensi yang diharapkan }
\end{array}
$$

\section{b. Pengujian Homogenitas}

Dari hasil perhitungan pengujian homogenitas varians populasi diperoleh nilai $F_{\text {hitung }}=1,15$ dan nilai $F_{\text {tabel }}=1,89$ karena $F_{\text {hitung }}<F_{\text {tabel, }}$ maka dapat disimpulkan bahwa data hasil belajar Fisika pada kedua kelas siswa berasal dari populasi yang homogen. (perhitungan selengkapnya dapat dilihat pada lampiran VIII)

c. Pengujian Hipotesis

Pengujian hipotesis dilakukan dengan uji Chi-Kuadrat dengan hipotesis sebagai berikut: "Terdapat perbedaan yang signifikan antara hasil belajar fisika siswa yang mengikuti pembelajaran melalui media gambar lewat komputer dibandingkan dengan siswa yang mengikuti pembelajaran secara konvensional pada siswa kelas X SMA Negeri 3 Makassar".

Hipotesis Statistik:

$\mathrm{H}_{0}: \mu_{1}=\mu_{2}$ : Tidak terdapat perbedaan yang signifikan antara hasil belajar siswa yang mengikuti pembelajaran melalui 
media gambar lewat komputer dibandingkan dengan siswa yang mengikuti pembelajaran secara konvensional pada siswa kelas X SMA Negeri 3 Makassar.

$\mathrm{H}_{1}: \mu_{1} \neq \mu_{2}$ : Terdapat perbedaan yang signifikan antara hasil belajar siswa yang mengikuti pembelajaran melalui media gambar lewat komputer dibandingkan dengan siswa yang mengikuti pembelajaran secara konvensional pada siswa kelas X SMA Negeri 3 Makassar.

Kriteria pengujian hipotesis yaitu hipotesis Ho diterima jika $x_{\text {hitung }}^{2}<$ $x_{(1-\alpha)(s-1)(k-1)}^{2}$ dan ditolak jika sebaliknya. Dengan taraf kepercayaan $\alpha$ $=0,05, \mathrm{~s}=$ jumlah sampel, dan $\mathrm{k}=$ jumlah kelas interval, maka dari tabel distribusi $x^{2}$ (chi-kuadrat) dengan $\mathrm{dk}=$ 0,05 diperoleh nilai $x_{\text {tabel }}^{2}=x_{(0,95)(4)}^{2}=$ 9,49 , sedangkan nilai $x_{\text {hitung }}^{2}=17,06$. Oleh karena $x_{\text {hitung }}^{2}>x_{(1-\alpha)(s-1)(k-1)}^{2}$, maka hipotesis $\mathrm{Ho}$ ditolak dan $\mathrm{H}_{1}$ diterima. (Data selengkapnya dapat dilihat pada lampiran X).

Berdasarkan hasil tersebut diatas, maka dapat dismpulkan $\mathrm{H}_{1}: \mu_{1} \neq \mu_{2}$ yaitu terdapat perbedaan yang signifikan antara hasil belajar fisika siswa yang mengikuti pembelajaran melalui media gambar lewat komputer dibandingkan dengan siswa yang mengikuti pembelajaran secara konvensional pada siswa kelas X SMA Negeri 3 Makassar.

\section{SIMPULAN DAN SARAN}

\section{Simpulan}

Berdasarkan hasil analisis data dan pembahasan maka dapat disimpulkan bahwa:

1. Terdapat perbedaan hasil belajar fisika siswa kelas X SMA Negeri 3 Makassar tahun pelajaran 2013/2014 yang mengikuti pembelajaran melalui penggunaan media gambar lewat komputer dengan hasil belajar fisika siswa kelas X SMA Negeri 3 Makassar tahun pelajaran 2008/2009 yang mengikuti pembelajaran secara konvensional.

2. Rerata skor hasil belajar fisika siswa kelas X SMA Negeri 3 Makassar tahun pelajaran 2013/2014 yang mengikuti pembelajaran dengan menggunakan media gambar lewat komputer lebih tinggi dibandingkan dengan rerata skor hasil belajar fisika siswa kelas X SMA Negeri 3 Makassar tahun pelajaran 2013/2014 yang mengikuti pembelajaran secara konvensional.

\section{Saran}

Berdasarkan kesimpulan, dikemukakan beberapa saran sebagai berikut :

1. Pembelajaran dengan menggunakan media gambar lewat komputer layak untuk dipertimbangkan menjadi pembelajaran alternatif dalam rangka meningkatkan hasil belajar fisika karena dengan pembelajaran ini siswa lebih tertarik dan bersemangat pada proses pembelajaran.

2. Perlu adanya penelitian lebih lanjut mengenai pembelajaran dengan menggunakan media gambar lewat komputer pada pokok bahasan yang lain.

3. Diharapkan kepada para peneliti selanjutnya agar dapat memanfaatkan alat teknologi lainnya sebagai media pembelajaran fisika

\section{DAFTAR PUSTAKA}

Anitah, dkk. (2007). Strategi Pembelajaran Matematika. Universitas Terbuka. Departemen Pendidikan Nasional : Jakarta.

Arikunto, S. (2006). Metode Belajar Mengajar; Rineka Cipta, Jakarta. 
Arikunto, S. (2005). Dasar-Dasar Evaluasi Pendidikan. Bumi Aksara; Jakarta.

Arikunto, S. (2002). Prosedur Penelitian Suatu Pendekatan Praktek. Rineka Cipta; Jakarta.

Euwe Van den Berg. (1991). Miskonsepsi Fisika dan Remediasi.Salatiga; Universitas Kristen Satya wacana.

Hadi, A. (2005). Metodologi Penelitian Pendidikan. Pustaka Setia; Bandung.

Haling dkk. (2007). Belajar dan Pembelajaran. Badan Penerbit UNM; Makassar.
Hamalik, O. (2001). Proses Belajar Mengajar. PT. Bumi Aksara; Bandung

Muhammad Natsir. (2006). Strategi Pembelajaran Fisika. Jurusan Fisika UNM; Makassar.

Sadiman dkk. (2008). Media Pendidikan. PT. Raya Grafindo Persada; Jakarta

Sahabuddin. (1999). Mengajar dan Belajar. Badan Penerbit UNM; Makassar

Slameto. (2003). Belajar dan factorfaktor yang mempengaruhinya.Rineka Cipta ; Jakarta 